\title{
Leveraging Interactivities on Social Networking Sites for EFL Learning
}

\author{
Liwei Hsu \\ Language Training Sector \\ 81271 No.1, Songhe Rd., Xiaogang Dist., Kaohsiung City, Taiwan \\ Tel: 886-7-8060505Ｅ-mail: liweihsu@mail.nkuht.edu.tw
}

Received: July 10, 2013 Accepted: July 29, 2013 Published: July 30, 2013

doi:10.5296/ijele.v1i3.4063 URL: http://dx.doi.org/10.5296/ijele.vli3.4063

\begin{abstract}
Social Networking Sites (SNS) have a high penetration rate among adolescents who are considered as the Net Generation. Many studies have shown that SNS can increase students' motivation to learn. Therefore, more and more instructors are trying to incorporate SNS into their delivery channels in order to better their student's learning outcomes. However, whether or not SNS effectively help students elevate their EFL learning performance still needs further investigation. This study plans to explore how EFL learners perceive SNS. A Facebook-based community of practice (CoP) was engineered by a group of English majors where English was the only language used. The study reports on a 3-month action research that monitored the EFL learners' engagements in Facebook's community of interest. The participants were forty-three English majors $(\mathrm{N}=43)$, freshmen from a university in southern Taiwan, who have been actively using Facebook for more than a year. The results of the study presented an interesting aspect of the students' engagements in the activities, which were greatly influenced by the nature of the instructional activities and the feedbacks posted by their peers. Furthermore, results of an AHP analysis pointed out that these EFL students preferred involvement in instructional activities via the Facebook platform. They valued the criterion of interactivities on Facebook, with the greatest weight obtained from an AHP.
\end{abstract}

Keywords: EFL Learning, Social Network Sites, Community of Practice, Analytical Hierarchical Process 


\section{Introduction}

Social Networking Sites (SNS) are prevalent among today's young adults because of the affordances of multifunctional devices. Students, as the major users of SNS, build up virtual identities, increase their engagements and form social relationships on sites, such as Facebook (Yu, 2010; Bumgarner, 2007; Stutzman, 2006). Moreover, the rapid development of information communication technology (ICT) has brought changes to both pedagogical applications and students' learning styles (Mazman, 2010). Being aware of the popularity of SNS among students, instructors started to integrate their instruction with them to accommodate their students' various learning styles. A handful of studies concerning the application of SNS in teaching showed that they could improve the students' general learning performance and strengthen learning motivation and autonomy (Pasfield-Neofitou, 2011; Kabilan, 2010; Mazman, 2010). However, questions such as: "Are SNS the ideal environment for English as a foreign language (EFL) learning?" and "Do EFL learners perceive SNS suitable platforms for acquiring better English skills?" remain unanswered. As of December 31, 2012, there were 13,240,660 Facebook subscribers in Taiwan, with a penetration rate of $57.0 \%$ (http://www.internetworldstats.com/asia.htm). This study is reporting the results of a 3-month action research that monitored EFL learners' engagements in a community of practice $(\mathrm{CoP})$ on Facebook. As such, results were triangulated with the administration of an Analytical Hierarchical Process (AHP) that invited participants to compare their preferences for learning EFL: either through traditional learning activities or through ICT-based CoP. This study aims to find out how, and in what ways social network sites help EFL learners to engage in activities conducted in English. Furthermore, this study is looking for factors that may affect a student's engagement. The research questions are listed as follows:

1. How do Net Generation EFL learners engage in social network sites as a platform for English learning?

2. What are the primary factors that affect their engagement in virtual CoP activities?

3. What channel do the EFL learners of the Net Generation prefer when interacting in English? SNS or FTF?

In order to properly address the proposed research questions, the framework for this study was structured as follows. The studies concerning ESL learning and Social Networking Sites affordance were reviewed. They outlined the rationale of the methodology adopted by this study. Research methods, include: research instruments, participants, procedures, data collection and a post analysis. The results and in-depth discussion follow the methodology. The final section is comprised of an interpretation of the findings, a discussion of the contributions and the study's limitations.

\section{Theoretical Background}

\subsection{Net Generation}

Young adults, born around 1982, have grown up with high exposure to information and 
communication technologies (ICT), which have become part of their daily lives. They are considered to be the Net Generation (Net Gener) (Sandars, 2007; Oblinger, 2005). The high prevalence and rapid development of ICT have influenced the way a Net Gener retrieves information. Studies conclude that while they are learning, Net Geners seek immediate feedback, accessibility to information, an interactive environment, multi-media application availability, teamwork with others, connectivity, hands-on experiences, inquiry-based approaches and self-directed learning opportunities(Glenn, 2000;Hay, 2000;Barnes, 2007;Arthur, 2006; McLoughlin, 2007). Moreover, Net Geners tend to be more independent and autonomic in their studies, and are more willing to explore knowledge rather than just simply absorb what is put in front of them (McLoughlin, 2007;Carlson, 2005;Hay, 2000). In other words, Net Geners hold a more positive and adventurous attitude toward learning, and they like exploring the unknown themselves.

Nevertheless, Net Geners also have shorter attention spans while reading online, or working on other activities (Berk, 2009).Nor do they effectively communicate in the conventional fashion (Feiertag \& Berge, 2008). Social networking sites such as Facebook are another option for socialization (Oblinger, 2008). They also tend to receive an immediate response for new knowledge with just a click on the mouse, through search engines such as Google (Oblinger, 2008). It is, therefore, important for higher education institutions and instructors to discover a new teaching model to cater to the various types of learning styles that will meet the Net Geners' needs(McLoughlin, 2007).

\subsection{Social Networking Sites (SNS)}

Just like personal websites and instant messages, Social Networking Sites (SNS) are platforms that provide an easily accessible way to connect and interact with others, by sharing ideas and opinions and gathering feedback in a fluid and dynamic way (McLoughlin, 2007; Pempek, 2009). A handful of studies have concluded that SNS provide several technological affordances such as immediacy, interactivity, and the opportunity to present a self-identity to users (Arthur, 2006; Bumgarner, 2007; Junco, 2011). Pempek (2009) argued that the difference between SNS and traditional media is that that SNS can interact with others directly in a virtual environment. Lin (2011) further suggested that virtually direct interaction makes SNS a useful and enjoyable medium of communication and keep people continuously engaged. Aware of the advantage of SNS, studies have examined the pedagogical possibility of using them in terms of EFL learning. Their results have indicated that it is feasible. Yunus, Salebi, and Chenzi (2012) suggested that the integration of SNS into the ESL writing classroom had a positive impact on broadening students' knowledge, by increasing their learning motivation. Mitchell's study (2012) investigated why EFL students use SNS and the results implied that they enable students to acquire English language as well as the culture. Since SNS have become such an influence in a student's daily life, a comprehensive understanding as to how they help students learn is crucial for both the academic and pedagogical community (Mazer, 2007). However, these aforementioned studies focused more on the effectiveness of integrating SNS into EFL education. As to how EFL learners perceive and further engage in activities on the SNS still calls for insightful exploration because the quality of their social interactivities depends greatly on the 
participants' contributions (Lee, 2004). This research is designed in accordance with a qualitative research design to provide a specific description on the use of SNS within the EFL learning context. Facebook, being one of the most popular and commonly used social networks, was chosen to examine EFL learners' engagements in activities administered with an established online community of practice.

\subsection{Online Communities of Practice (CoP)}

The term communities of practice (CoP) was coined by Lave and Wenger (1991)when they organized an informal group to share specialized knowledge. Albeit, this term made its emergence from an anthropological viewpoint: but has been popularly adopted by course designers in an educational setting. In the process of knowledge sharing, different CoPs can be assembled into CoIs (Communities of Interest) on the basis of members' having similar interests (Rachel, 2008; Huang et al., 2010). This study's CoP concept is identical to a CoI, because members of this community share the same interests, but under the supervision of a facilitator. Within the virtual context, various types of CoIs have been established at an astonishing speed, along with the development of social network sites such as Facebook and MySpace (Ellison, Steinfield \& Lampe, 2007). Therefore, geographic boundaries can be broken down by means of forming online connections (Kaulback \& Bergtholdt, 2008). The notion of a CoP for learning a language is very similar to the term "speech community" and engagements in such communities may enhance an individual's sociolinguistic competencies (Holmes \& Meyerhoff, 1999). Any EFL environmental disadvantages can be compensated through online networks with native English speakers.

However, the CoP's application will not lead to optimal effectiveness naturally. The role of members, who have higher competency levels, is significantly relevant to the effectiveness of a CoP, particularly in foreign language educational settings(Haneda, 1997). In a case study conducted by Morita (2004), Japanese L2 English learners engaged more in CoP activities if the teacher acknowledged their contributions. With such a rich linguistic resource available in a CoP, students' learning effectiveness may be improved through active participation in the activities (Jou, 2013; Swain \& Deters, 2007). Nevertheless, the CoPs constructed by the aforementioned research were led or dominated by native speakers of the target language. The outcomes may be different if the CoP is established voluntarily by learners within an EFL context where no native English speakers are involved, especially when it uses a virtual environment such as the Facebook as its platform. This was the catalyst for designing this research.

\subsection{L2 Socialization}

Language socialization is broadly defined as the process through which a child or other novice acquires language knowledge and practices. These will enable him/her to participate effectively and appropriately in the social life of a particular community having their own values, ideologies and activities, and enabling them to be recognized by other members (Garrett, 2002; Duff, 2007). Second language socialization (L2 socialization) is the process where a novice is socialized into the target language community through the use of that particular language. In order to foster a second language socialization and to boost second 
language learning, from the perspective of a Social Cultural Theory, Lantolf (2007) emphasized that being exposed to the target language is necessary. A Sociocultural Theory, as well as L2 Socialization, as Kasper (2001) suggested, occurs when the knowledge of the target language is not only transmitted, but also created and acquired through concrete interaction in an appropriate sociocultural environment. That is to say, abundant interaction in a target language community is important to second language learning; otherwise, the process and learning outcome is compromised (Norton, 2008).

$\mathrm{Xu}$ (2010) further pointed out that negotiations between learners and interlocutors are the essence of language development, which should include comprehensible as well as incomprehensible input. Since negotiations and interactivities of L2 socialization can enhance the rate of acquisition (Nation, 2001), an EFL learner's active and positive participation in an English cultural community and activities, is essential for the effective learning of the language (Lantolf, 2007; McLoughlin, 2007; Ricento, 2005). Furthermore, in Kim's (2011) study, non-native English speakers were keen to make more contributions in the virtual community of practice than their native-speaker counterparts, because their confidence was piqued by the interactivities. One of the most important tasks for EFL teachers is to promote their student's engagement in English, in a formal as well as informal educational context, which can be achieved through meaningful interactions under the auspices of Computer-mediated communication (CMC)(Yang, 2011).

However, to our knowledge, any empirical work on Chinese-speaking EFL learners' behavior on SNS such as Facebook is still at an early stage, particularly when applying an Analytical Hierarchical Process (AHP) as a tool for empirical analysis.

\subsection{Identity}

Identification occurs when one wants to establish or maintain a satisfying self-defining relationship with another person or a group, and is crucial for individual socialization and language acquisition (Norton, 2002). Members' identification within a virtual learning community plays a vital role in knowledge sharing or contributing to social activities (Chow, 2008; Hooff, 2009; 2008;Shin, 2007). Language acquisition engages the students' identities since language itself is not only a linguistic system of signs and symbols but also a complex social practice (Norton, 2002). When a language student interacts with members of a target language group, he/she is seeking more than just words, phrases, dialect, and idiomatic expressions, but rather to what extent he/she will be able to impose reception and be recognized by his/her interlocutors (Norton, 2002). The identification level of bilingual identity is also influenced by the learners' perceptions and attitudes toward the learning environment (Ghazvini, 2011). SNS are an ideal place for EFL learners to access a target language and create a virtual identity (Reinhardt, 2010; Yu, 2010). Exhibiting the potential as platforms for community participation and self-presentation construction they allow students to stay active within various interactions, and maintain close relationships with a small group of peers. Ricento (2005)and Ushioda (2011)suggested that the higher the degree to which a learner identifies with a target culture, the more motivated he/she will be to acquire that language. By engaging in self-expression, conversation and knowledge sharing with others 
on SNS, ESL learners form their virtual social identity and master the target languagesimultaneously (McLoughlin, 2007). A few empirical studies have already been done concerning EFL learning on SNS. This study aims to empirically extend the current understanding of this issue.

\subsection{Collaborative Learning}

Collaborative learning is defined as a way to jump-start a learners' cognitive development through social interactions or knowledge sharing in an enjoyable fashion (Zurita, 2004; Olivares, 2007; Minocha, 2009). This has been proven to effectively improve learning outcomes (Cheng, 2011). Learners are able to retain the knowledge they acquire through collaborative learning much longer (Ge, 2011). Based on Brown and Ford's statement (2002), the advantage to collaborative learning comes from two major areas: information retrieval and increased motivation. These two advantages are acknowledged to be the major reasons attributed to learners' outperformance. In the digital era, integrating the collaborative learning paradigm with the virtual context, which is also known as Computer-supported collaborative learning (CSCL), has attracted the attention of many scholars (Chen, 2012). Within the domain of EFL learning, students' engagements in Facebook or other CMC platforms did promote collaborative learning between them (Lampe, 2011; Ko, 2012); however, it will not naturally occur in a virtual environment (Orvis, 2006; Hsu\& Lin, 2008). It is assumed that students need to perceive the benefits of learning through their interactions on Facebook, or any other virtual platform, before they are motivated to make a contribution. Pertinent research, comparing learners' feedback on collaborative learning in traditional classrooms and CSCL remains very limited, particularly when EFL learning is the focus. Research conducted by Warschauer (2002) and Ge (2011) focused their analysis on the ESL/EFL students' English writing abilities. Results from these two studies indicated that the CSCL had a positive effect on learning. How and why CSCL facilitates collaborative learning is still unclear. At the time of this writing, no studies have applied a decision-making technique, such as AHP, to help learners recognize their preferences between CSCL and face-to-face collaborative learning.

\section{Research Context}

This study designed and orchestrated an Analytical Hierarchical Process (AHP), as a qualitative method, to provide detailed information and comprehensive answers to the proposed research questions. Facebook was also used to organize a community of practice $(\mathrm{CoP})$ in an experimental context for EFL pupils, due to its prevailing popularity among the college students in both southern Taiwan (Shih, 2011)and other corners of the globe(Junco, 2011). The CoP was formed voluntarily by freshmen of a public university in southern Taiwan as they were interested in learning English and wanted to have more interactions within a virtual environment (i.e. Facebook).All of the participants $(\mathrm{N}=43)$ were English majors, and a facilitator who had a professional English background (a nonnative speaker EFL teacher) was invited into the $\mathrm{CoP}$ as the English expert in this virtual environment. It is noted that the facilitator would provide the appropriate English language usage to a participant during discussions within the CoP, but only when needed, and did not actively 
commence any activity. Participants were encouraged to post and initiate all sorts of materials (e.g., movie clips, music, articles, etc.) and activities in the CoP. Consequently they would have responses and discussions under those postings that interested them. English was the only medium being used within this $\mathrm{CoP}$ and no newcomers were invited to join in during the research period.

The major activities conducted in this CoP were for the purpose of leisure and therefore mainly about, but not limited to, members' sharing their thoughts on a movie or song that they had just seen or listened to. They would comment on the contents of that movie or song per se or they could express their viewpoint regarding the performance of an actor/actress, or singer/band. Their personal stories were also welcome as long as they felt comfortable sharing. The role that the facilitator played in this CoP was to promote the interactivities between members and to provide feedback on their use of English. The facilitator rarely actively initiated an interaction unless there had been no interactivity undertaken by members for a certain period of time (i.e. 3 days).

\subsection{Qualitative Methodology of this Study}

The qualitative design for this study was to obtain "detailed descriptions of situations, events, people, interactions, and observed behaviors; direct quotations from people about their experiences, attitudes, beliefs, and thoughts; and excerpts or entire passages from documents, correspondence, records, and case histories" (Merriam \& Simpson, 1995, p. 157). In social science research, focus group interviews have been acknowledged as the popular method for collecting qualitative data (Denzin \& Lincoln, 2000; Graffigna \& Bosio, 2006; Rodriguez, Schwartz, Lahman, \& Geist, 2011) and was thus adopted by this research. The main reason for utilizing this method was its ability to facilitate the interviewees' self-disclosures within the group (Krueger \& Casey, 2009). More personal viewpoints and opinions could be elicited from the participants since they were given greater control in the research, which can make new information more meaningful (Jowett \& O'Toole, 2006). The reliability of collected qualitative data could be scrutinized through the triangulation of data sources which would ensure its trustworthiness, dependability, transferability, and conformability (Lincoln \& Cuba, 1985). The participants were from the same class and acquainted with each other, which implied that they would feel totally comfortable sharing their unique experiences with the interviewer(Rodriguez et al., 2011).Their role is to be decisive about the quality of acquired qualitative data. They are supposed to understand and value the interviewees' experience or story that was shared within the group, to garner rich and authentic information (Fallon \& Brown, 2002; Hennick, 2008). As for ethical concerns, all participants were informed upon undertaking this research that they were free to be excluded at his/her will as it would not harm or breach their rights.

In addition to a focus group interview, virtual observations were used to record the participants' engagements in the virtual CoP because "anchoring analytical observations firmly in data is simply imperative in all qualitative analysis" (Nikander, 2008, p. 225). The objectivity issue with observations has raised concerns from researchers, such as Denzin and Lincoln (2000) as to the validity of qualitative research. In order to assure the objectivity of 
observations, the researchers, as well as the CoP facilitator, did not share their personal thoughts at the CoP. With regards to reliability of the qualitative data a member-checking technique was administered, by asking participants to examine the correctness and clarification of the interview transcripts. Validity can be ensured once participants' masking behaviors, or responses can be avoided when participants feel the researcher(s) is/are trustworthy (Jowett \& O'Toole, 2006).

\subsection{Instrument}

The major instruments used by this research were a structured interview, virtual observations and an AHP. Interview questions were developed on the basis of reviewed literatures and were used to obtain the participants' general understanding of using Facebook as a language-acquisition platform, and their specific opinions towards interaction with their peers within this CoP. The AHP questionnaire was designed to assist the participants in eliciting their preference between doing activities face-to-face or having these activities on Facebook. Due to the attributes of AHP, the Likert Scale was not suitable for pair-wise comparisons (Hsu, 2011;Kainulainen, 2009).Instead, an AHP questionnaire has the ability to evaluate an individual's preference regarding two items on the same nine level preference scale, both quantitatively and qualitatively (Ishizaka\& Labib, 2009).

As mentioned above, an AHP is a theory adopted in the decision-making process through measurements of pairwise comparisons between two options (Saaty, 2008). With the administration of an AHP, the relative importance between two possible solutions can be derived in numerical values (Saaty, 1994). An AHP has been applied as a tool to depict and evaluate the relationships among variables (Huang, 2011; Saaty, 1990), particularly when innovative educational approaches are studied and compared to conventional pedagogy (Shee, 2008; Huang, 2011). For this research, twenty participants were randomly selected to serve as a panel of members to fill out an AHP questionnaire, that was designed to help participants respond regarding their preference for interactivities either on Facebook, or face-to-face. Questions in each construct were developed on the basis of the underpinning theories discussed above. Sample questions for the "Negotiation" construct began with "I feel more comfortable asking questions or making responses to others in English", and the "Interactivities" construct included statements such as: "I like to interact with other members within this community". The "Identity" construct consisted of two variables:"relationship with other members" as well as a "sense of belonging to the CoP". Sample questions from these two variables began with "I have closer relationships with my peers" and "I feel stronger bonding to the CoP", respectively. The third proposed construct was "Collaborative Learning" comprised of "motivation to make a contribution" and "pleasure of interactions". Sample statements for these two variables included: "I have a stronger motivation to engage in communications" and "I had fun communicating."

Participants were asked to make the pairwise comparison between Facebook and face-to-face modalities on a scale of 10 . The weights for each criteria/sub-criteria were calculated and evaluated for objective and scientific results (Badri, 2004).An Expert Choice Software Pack was used to conduct the AHP analysis. 


\section{1ll Macrothink \\ International Journal of English Language Education \\ ISSN 2325-0887 \\ 2013, Vol. 1, No. 3}

\subsection{Procedure}

In April 2011, the participants themselves, formed a Facebook CoP as a means of improving their English communicative competence. The facilitator, who had been invited by these participants, played a passive role at its inception, i.e. the facilitator did not actively initiate any activities for the CoP. The activities originated with the participants. The observations were conducted in April of the same year, and lasted for three months. Focus group interviews were conducted at the end of the semester, for cross-analysis with data derived from the observations, and each participant's posts within the CoP. At the end of this study, an AHP was adopted to extract answers to the fourth research question.

\subsection{Participants and Data Collection}

Forty-three English major freshmen $(\mathrm{N}=43)$, withhigh/intermediate levels of English proficiency, from the National Kaohsiung University of Hospitality and Tourism, participated in this study. The average age was $19(\mathrm{SD}=0.95)$ with the majority being females (around $70 \%$ of the participants). Most of them had actively experienced using Facebook for more than a year. According to the suggestion by Powell \& Single (1996), the focus group should be comprised of between six to ten individuals with a similar key characteristic, related to the research. This study invited six members of the CoPin for a focus group interview. Postings on the Community of Practice (CoP) on Facebook were also used for analysis, and the conversations in the focus group interview were recorded using digital voice recorders, and transcribed verbatim. For the AHP analysis, twenty participants were selected from this pool of participants. These twenty had experienced learning EFL through both Facebook and face-to-face encounters.

The data collected from various sources (postings, interview responses, observations, as well as AHP) were coded and triangulated to enhance reliability and validity. The content analysis was adopted to systematically refine the participants' responses and feedback. Cross-analyses were conducted afterwards, to acquire insightful information about the experience. The participants' responses to the AHP questionnaire were analyzed with the Expert Choice 2000 software to yield normalized priority weights for each factor (Tama, 2001). The proposed AHP network is presented in Fig. 1. 


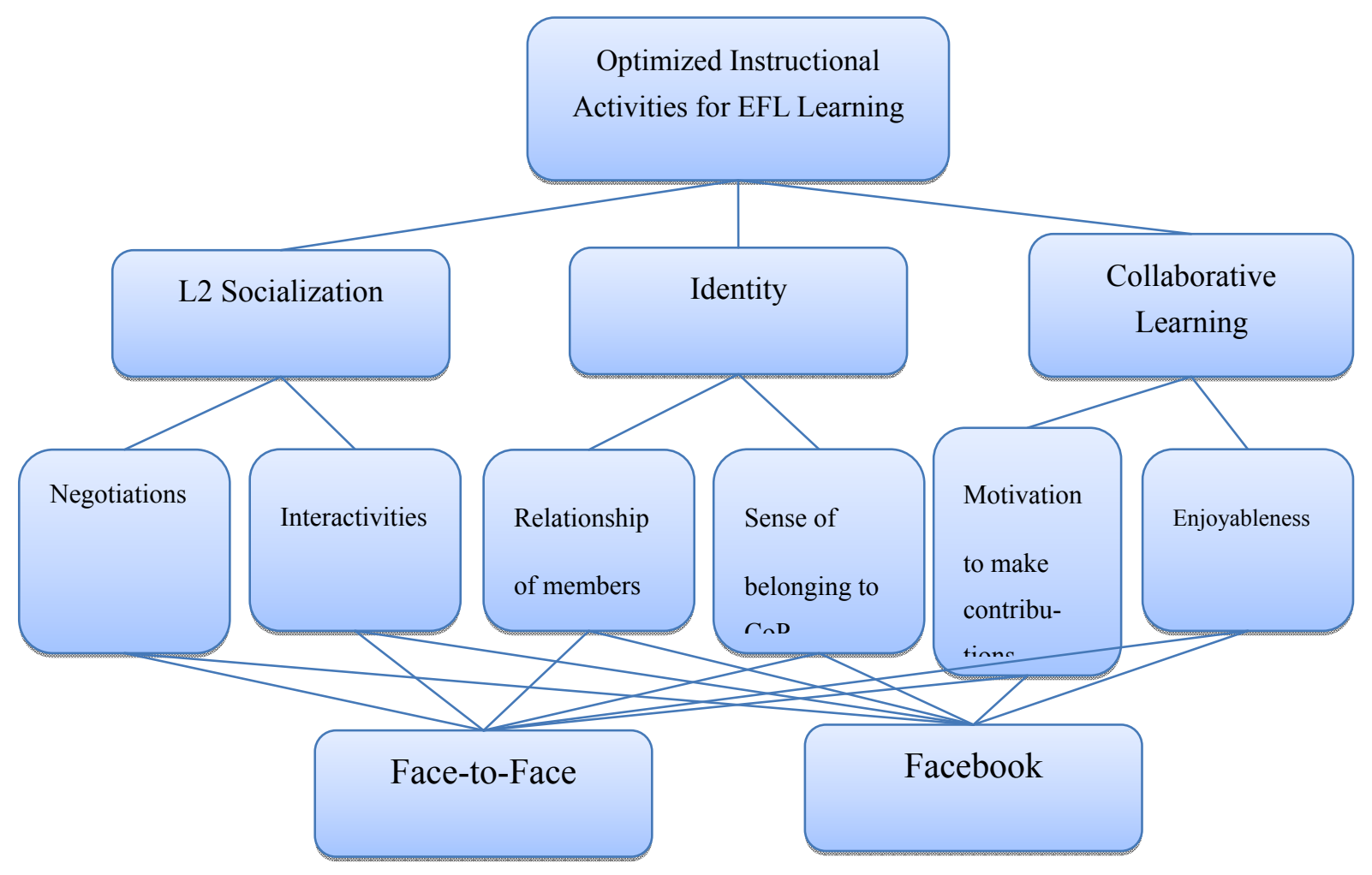

Figure 1. Proposed Structure of AHP Analysis

\section{Findingsand Discussions}

After observationswere completed and any conversations posted on Facebook were collected and coded,the study undertook focus-group interviews to further determine the causes of the participants' behavior. The study's results and findings are outlined and described on the basis of three proposed questions. Various data sources are presented to provide a comprehensive view of the facts.

\subsection{How do Net Generation EFL Learners Engage in Social Network Sites as a Platform for English Learning?}

Virtual observations were used to analyze participants' interactivities within the CoP. Here the participants were encouraged to post and share with others anything that interested them, such as movie clips, music videos or inspiring quotations. Most of the participants were motivated to take part in the interactions, and were keenly engaged for the first few weeks. There were 50 postings within the first two weeks for a total of 57 in April. However, the number of postings decreased dramatically in the following months. There were 54 postings in May and only 11 in June. Once this inactivity was noted the facilitator tried encouraging the participants by posting different kinds of materials and raising their interest with various topics. Nevertheless, the participants' engagement was still not boosted significantly. Figures below reflect such changes, i.e., Figure 2 shows the participants' active engagement because 
the topic appealed to them. On the other hand, when a passage on globalization trends was posted, interactions or discussions decreased dramatically (Figures 3 and 4). The participants made zero contributions, even though the facilitator encouraged further engagement. They started to re-engage only after the facilitator compromised on the choice of topics (Figure 5).

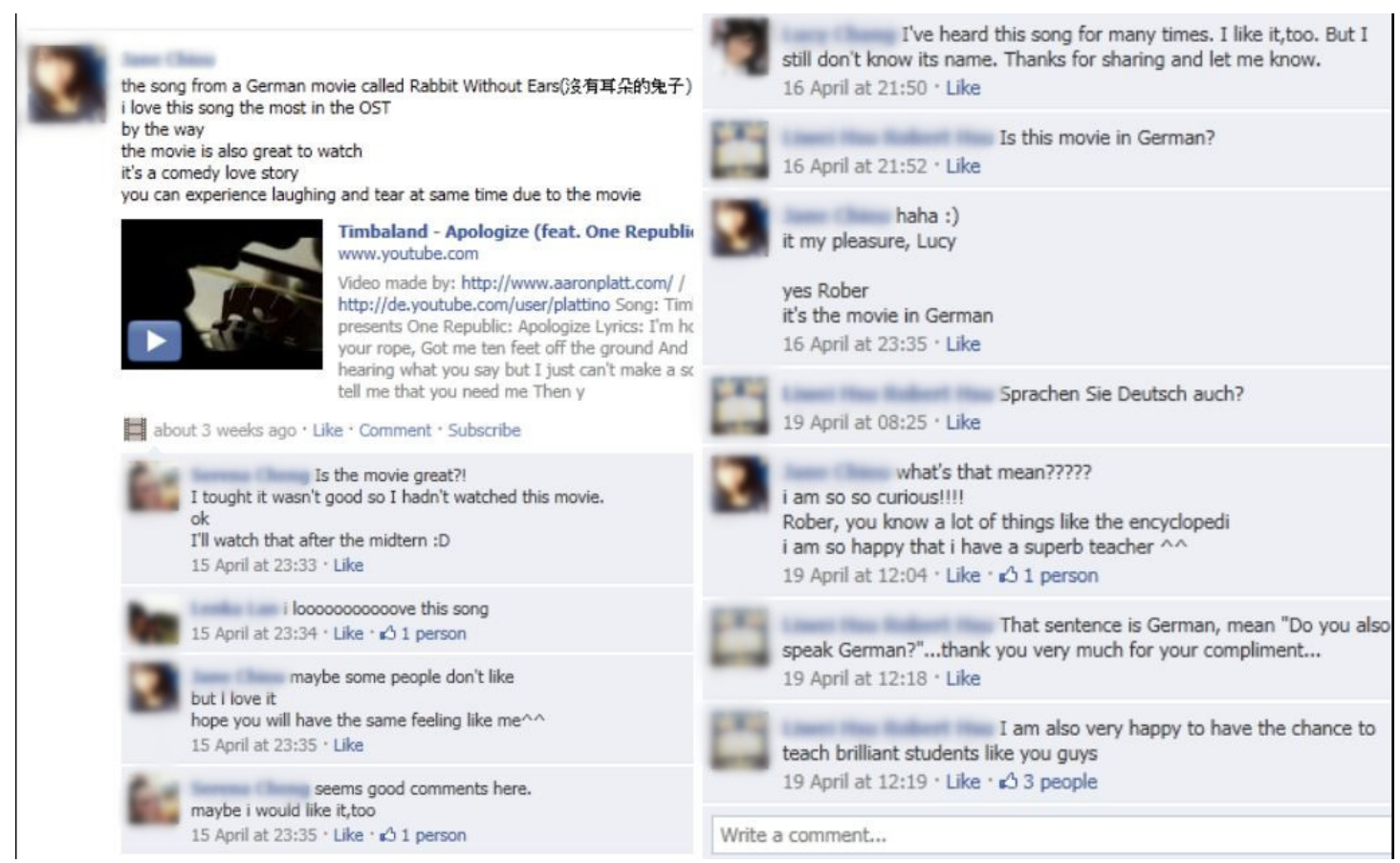

Figure 2. Participants' Active Engagements

\section{Reading message1 IELTS Reading comprehension}

In an age of globalization, collaboration and strategic alliances may be essential to success. Of course, there have traditionally been a number of ways to cooperate, including mergers in which two companies form a legal union, or a joint venture where several companies pool resources to create a separate entity. However, a strategic alliance is much less involved than either a merger or a joint venture. Quite simply, a strategic alliance is a mutual agreement between two or more companies in order to work more effectively toward their goals. This usually involves a plan to share resources for mutual benefit. For example, one company may have financial resources and another company may have technical expertise. By combining these resources, both companies would increase profit. In some cases, one company may possess a brand name that would provide a marketing advantage to another company whose product is relatively unknown but has huge sales potential. In other cases, international strategic alliances open new markets aboard to companies that have a product but lack expertise in advertising for that market segment.

As compared with other options for cooperation, the major advantage of strategic alliances is that they may be easily formed and easily dissolved, which makes them a perfect vehicle in a rapidly changing business environment. When a mutual goal has been attained, the alliance may no longer be beneficial, and, unlike mergers or joint ventures, which have more long-term implications, partners in an alliance can come together for short-term collaboration and then realign themselves with other strategic partners when the markets shift or new technologies require different strategies.

After reading the article, please answer the following questions:

Q1: What is the main idea of this article?

Figure 3. Sample of IELTS Reading Test 
After reading the article, please answer the following questions:

Q1: What is the main idea of this article?

Q2: Describe the difference between collaboration and strategic alliances in your ow word.

Q3: If you are a boss, which method would you adopt? Why?

Q4: What is the author's attitude toward collaboration and strategic alliance betweet two business entities?

Q5: . Based on the information conveyed in the article, can you describe the pros and cons of collaboration and strategic alliance for the operation of a company?

Like · Comment - Unfollow Post - 01 May at 02:39

10 This is the article for week 1

01 May at 02:39 - Like

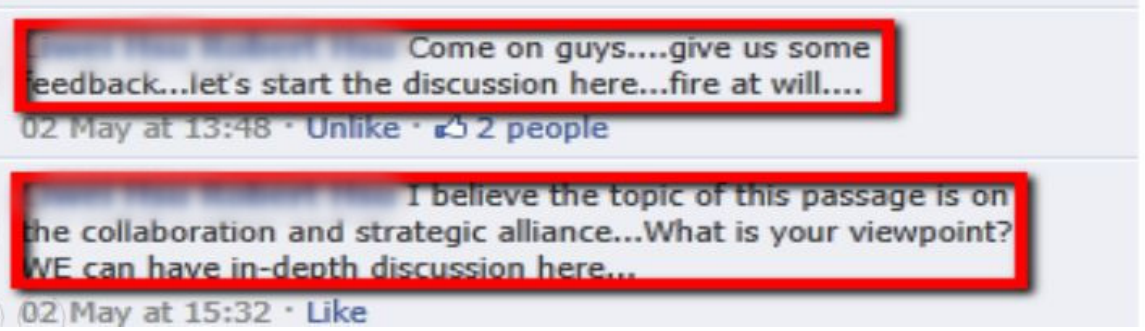

Figure 4. Facilitator's Encouragement for More Inputs

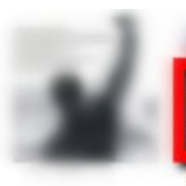

All right guys, I realize that the reading passage is long and tedious, which is a bit overwhelming to you. So I am going to adopt another way to conduct the activity. Any one or you may choose a song that you d ike to share with us. You also wiil need to provide us with the reason why you choose this song. The rest of you are expected to look for the lyrics and discuss the wordings of lyricss. This type of activities should arouse your interest better than the reading comprehension, right?

Unlike · Comment · Unfollow Post · 04 May at 02:14

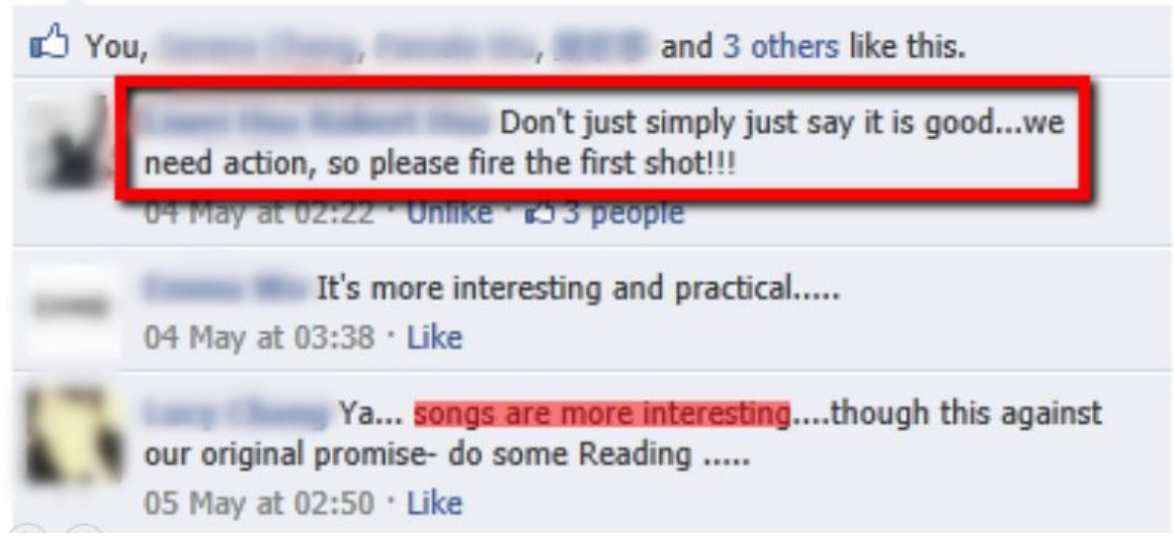

Figure 5. Change of Topic

According to this finding, it is safe to say that the topic of the activities seemed to be more critical to the participants' engagement, than the facilitator's encouragement. Therefore, in EFL learning, the major task for the online facilitator is choosing themes to boost the 
participants' interest, not just cheerleading. Another interesting point to emerge, was that students did not seem to really develop an interest in continuing with the CoP beyond the first two weeks once their initialenthusiasm for using the new toy (i.e. Facebook) had abated. After a certain period of time "having fun", they suddenly got bored, which reflected another major characteristic of Net Geners(Feiertag \& Berge, 2008; Oblinger, 2008). Given the fact that Net Geners' get easily bored, in addition to the novelty aspect, instructors will have to give Facebook serious consideration before using it as a platform to teach, or learn English as a foreign language.

When the quality of their engagements was taken into account, it was clear that participants contributed and engaged in interactions when more "meaningful" input was the main focus. In light of that, they were encouraged to express their feelings on a specific movie or song, and the wording of their contributions was used for further analysis. Functional words were singled out, and the number of content words counted for meaningful input. However, just like the changing frequencies of their engagements, the quality of contributions also declined. These were assessed, on the basis of the number of content words, as participants' meaningful contributions. Results showed that both the quantity and quality of participants' contributions fluctuated dramatically, which was in line with the study conducted by Miceli, Murray, and Kennedy (2010) and once again, the reason could be attributable to the negotiated topics. Therefore, this study provided evidence to support the statement that the instructional design of online curriculum should be the CALL teachers' main concern because it dominates the learning outcomes (Ko, 2012; Levy, 2009; Colpaert, 2006).Further details on the reasons for this change will be presented in the following sections.

\subsection{What are the Primary Factors Affecting EFL Learners' Engagements in the Virtual CoP's Activities?}

According to the virtual observations, participants' engagements could not be maintained but could be altered by external influences, such as the discussion topics. In order to find the reason behind the engagement loss, focus group interviews were conducted to explore participants' opinions toward interactions in the CoP and on Facebook, and the factors affecting their motivation and engagement.

The interviewees reported that, generally, they enjoyed interacting with peers within the CoP on Facebook because they thought it was an ideal place to be immersed in English (Pasfield-Neofitou, 2011), an essential element for EFL learners acquiring this language. They also felt that they could improve their English proficiency through interactions and negotiations, within the CoP, along with their peers and the facilitator, who could guide them in the use of the correct English expressions. Some participants even indicated that expressions could be more accurately conveyed in English and wanted to make English part of their lives.

\section{Interviewer: How do you like to interact with people in English on Facebook?}

Interviewee 3: "I like it."

Interviewee 4: "I enjoy this type of activities too." 
Interviewer: You like it? Why?

Interviewee 4: "I think that sometimes we can use English words to express ourselves. The meaning of these words can truly express my thoughts better than using Chinese. Sometimes, in Chinese, you can't find a word that is maybe as strong, or just what you want to say."

Interviewee 2: "Because I think it is easy to handle English, not like homework or some other pressure, so I like it. I think using English will be a lifestyle, and we can better fit ourselves into the English lifestyle quickly."

The interviewees reported that the current CoP is seen as a pressure-free environment for learning English because it is virtually a closed group with limited members, which puts them at ease. However, sometimes the students felt embarrassed and nervous when engaging directly in English with peers in their daily lives or in the open environment on Facebook, as they were concerned about using incorrect language in public. This result concurred with Lai \& Gu's (2011) study which proposed that, in comparison to other online platforms, such as Wiki and blogs, for language learners' socialization, Facebook can "justify their niches in the out-of-class learning context" (p. 330).

Interviewer: So you are willing to use English on Facebook?

Interviewee 3: Because we don't need to confront the situation directly...because when we talk to each other in English, I get embarrassed and anxious if some difficult words are used that I don't understand. It is different on Facebook because I can just go look the word up in the dictionary, then come back and reply.

Audience is an important factor affecting the engagement and motivation to interact in English on Facebook's open environment. For example, if participants are aware that their posting will be read by their English teacher or the Chair of the department, they will alter their word choice and be more careful making statements because they worry about making mistakes when posting or responding in English. In other words, participants will be more cautious about their grammar or writing style if they expect their posts to be reviewed by those who have higher levels of proficiency in English. Such self-awareness may be of great benefit to EFL learners but their affective filter will exist as well. Empirical evidence will be needed to confirm this statement.

Interviewer: So if it is an open environment. In other words, other people will see your English writing, for example, maybe Goodman (one native English speaking teacher) will look at your posting. Would your motivation for engagement be different?

Interviewee 6: "No! If he sees my English writing, I will be hesitant about making contributions"

Interviewee 4: "Lower, a little bit lower." 


\section{Macrothink Institute ${ }^{\mathrm{TM}}$}

Interviewer: Why? You worried about them is takes that you may make in the postings?

Interviewees 3, 4\& 5: "Yes!"

Interviewee 2: "Because I think this online community is not an open one so we don't have any pressure. It's free to say everything here."

Interviewer: But if the Chair of the Department is checking, would you use this informal way to express yourself or would you change your writing style?

All of the Interviewees said: "Change some words." Or "I will be careful about the word selection."

Interviewer: You won't be that free to do or to write anything you like.

Interviewee 2: Of course, and I will probably not make any engagement if I am aware that there may be some people I don't know who will see my postings.

Interviewee 5: "Yes!"

The amount of feedback plays an important role in the participants' motivation and engagement with the CoP. The interviewees reported that they expected a lot of responses when posting something in the CoP. They expected specific oral feedback. They thought that clicking on "Like" would not be regarded as a specific response to a posting. In fact, a large number of responses and by hitting "Like" made them feel that they had been heard, recognized and understood by peers. This appeared to increase the participants' sense of achievement and the likelihood of their continued engagement in the L2 online use (Pasfield-Neofitou, 2011). However, the amount of feedback depended heavily on the topic. If most participants felt that the topic was interesting, they would be enthusiastic about providing feedback. On the contrary, if the participants were not interested in the topic, they might remain silent, which would decrease their motivation in the long term.

Interviewer: All right, after you post something on Facebook, would you expect a lot of feedback?

All the interviewees said: "Yes!", "Sure!" and "Of course!"

Interviewer: What if some people just click on "Like" and make no response? How do you feel about that kind of action?

Interviewee 3: "Well, I know that some people just enjoy "liking" every post but I would encourage them to reply."

Interviewee 5: "Clicking on "Like" means nothing."

Interviewee 1: Hahaha...I have to admit that I am the one who tends to click on "like" but make no response...Sometimes I just want to be actively socialized in this community and therefore try to be nice to all the posts.

Interviewer: So you like to see their reply in words, not just "Like"? 
Interviewee 5: "Yes, because more and more people press "Like", so it is common to press "Like."

Interviewee 4: Well...getting "Like" as a comment on my post is better than having no response at all...

Upcoming assignments and examinations involved other factors affecting the participants' motivation and engagement. The interviewees reported that when a big exam was imminent or an assignment was due, they would be too busy and too tired to follow postings within the CoP. However, they also suggested that, if the topic was interesting enough, they would still engage in discussions within the $\mathrm{CoP}$ even though they still had lots of work. Finally, the novelty aspect could be found in both observations and the interview.

\section{Interviewer: So what influences your motivation more? The topic or things like homework?}

All the interviewees: "Topic"

Interviewee 3: "If the topic interests me, I'll make some response no matter how tired I am or how much homework I have."

Interviewee 1: "And there will be a lot of people clicking on "Like".

The novelty aspect could be one factor affecting participants' motivation and engagement at the beginning of the CoP. Participants are attracted to the novelty of using English on Facebook. Yet, when the novelty abated, they became inactive. Moreover, they started to feel pressure since activity in the $\mathrm{CoP}$ was just like homework, only done on Facebook. In this way, the EFL learners' motivation for active online interaction lowers(Nor, Hamat, \& Embi, 2012). Based upon this finding, this study supported the statement byMontero, Watts, and Garcia-Carbonell (2007) which explicitly argued that online interactivities did not warrant learners' self-regulated participation in a CoP.

\section{Interviewer: Why did you guys engage more at the very beginning?}

Interviewee 3: "Because we think it is fun. It's a new thing. We haven't created a group like that before. We can post our favorite music, videos, and films on it.

During the research period, significant samples were selected from the six interviewees, in order to investigate their engagement within the CoP. A cross-analysis was then conducted based on the data derived from observations and two of the participants' posts.

Interviewee 3 had a relatively high engagement, made 14 posts, clicked on "Like" 10 times and placed 110 feedbacks in total. She was thoroughly engaged during the three-month period. On the other hand, Interviewee 5 made 2 posts, clicked on "Like" 8 times and placed 5 feedbacks during the research period. Most of these engagements appeared during the first week. This data showed that there were significant differences between these two participants in regards to their activity levels. From our observations, Interviewee 5 seemed to be affected by the novelty aspect more than other interviewees, since her engagements were concentrated at the beginning of the research period. In fact, the novelty effect was clearly identifiable at 
the beginning of this CoP, with 50 postings in the first two weeks. Determining how to lower the influence of the novelty aspect is an important issue in attempting to maintain the students' motivation and engagement within the CoP. During the interview, all the interviewees reported that they thought that using English on Facebook would be fun and that they would continue their engagement, as illustrated below.

Interviewer: So you think that using English on Facebook will be fun?

All the interviewees said: "Yes!"

Interviewer: OK so if you have the chance, will you continue using it?

All the interviewees said: "Yes!"

However, taking Interviewee 5 for example, although she agreed that using English on Facebook was fun, her active engagement did not increase. The reasons leading to her inactivity could be varied. Topic preference and concern about using incorrect English are possible reasons. Since the $\mathrm{CoP}$ on Facebook is a virtual group, it was not possible to weigh how much each participant was engaged in activities within the CoP. It would, therefore, be difficult to find out what really interested the inactive participants since they never expressed an opinion. In this case, with 43 participants in the CoP, only 25 of them ever engaged in it by either by placing a comment or posting something. Determining how to increase the inactive participants' motivation and engagement toward the $\mathrm{CoP}$ is a challenge for sustaining this CoP.

5.3 What channel do EFL learners of Net Generation prefer when interacting in English -SNS or FTF?

To effectively explore this question, an Analytic Hierarchical Process (AHP) was employed. Before an AHP analysis is undertaken, a consistency check must be administered (Ishizaka, 2009). The results for this study's consistency check received a high consistency (Inconsistency $=.00$ ) on all pair comparisons, which confirmed that it was consistent on all levels (Shee, 2008; Badri, 2004). The weights of all dimensions and criterions are presented in Table 1 below:

Table 1. Results of AHP

\begin{tabular}{|c|c|c|c|}
\hline Level 1 & Level 2 & Alts & Prty \\
\hline \multirow{4}{*}{$\begin{array}{l}\text { L2 Socialization } \\
\text { (L: .500) }\end{array}$} & \multirow{2}{*}{$\begin{array}{l}\text { Comprehensible } \\
\text { inputs in English } \\
\text { (L: .200; G: .100) }\end{array}$} & Face-to-Face & .039 \\
\hline & & Facebook & .079 \\
\hline & \multirow{2}{*}{$\begin{array}{l}\text { Interactivities } \\
\text { (L: .800; G: .400) }\end{array}$} & Face-to-Face & .063 \\
\hline & & Facebook & .315 \\
\hline \multirow[t]{2}{*}{$\begin{array}{l}\text { Identity } \\
\text { (L: .083) }\end{array}$} & \multirow{2}{*}{$\begin{array}{l}\text { Relationship of } \\
\text { members within } \\
\text { the CoP } \\
\text { (L: .750; G: .062) }\end{array}$} & Face-to-Face & .049 \\
\hline & & Facebook & .025 \\
\hline
\end{tabular}




\begin{tabular}{|c|c|c|c|}
\hline & Sense of belonging & Face-to-Face & .004 \\
\hline & (L: .250; G: .021) & Facebook & .016 \\
\hline \multirow{4}{*}{$\begin{array}{l}\text { Collaborative } \\
\text { Learning } \\
\text { (L: .417) }\end{array}$} & \multirow{2}{*}{$\begin{array}{l}\text { Motivation to } \\
\text { make contributions } \\
\text { (L: .250; G: .104) }\end{array}$} & Face-to-Face & .041 \\
\hline & & Facebook & .082 \\
\hline & \multirow{2}{*}{$\begin{array}{l}\text { Enjoyableness of } \\
\text { learning } \\
\text { (L: .750; G: .312) }\end{array}$} & Face-to-Face & .041 \\
\hline & & Facebook & .240 \\
\hline
\end{tabular}

The final phase foran AHP analysis is the sensitivity analysis (Ishizaka \&Labib, 2009). This examines and further confirms the stability of the research results placed in different positions of the hierarchy,when influenced by various factors. The outcome of the sensitivity analysis confirmed the fact that participants preferred instructional activities being tackled through Facebook. Detailed information on the sensitivity analysis is shown in Figure 6.

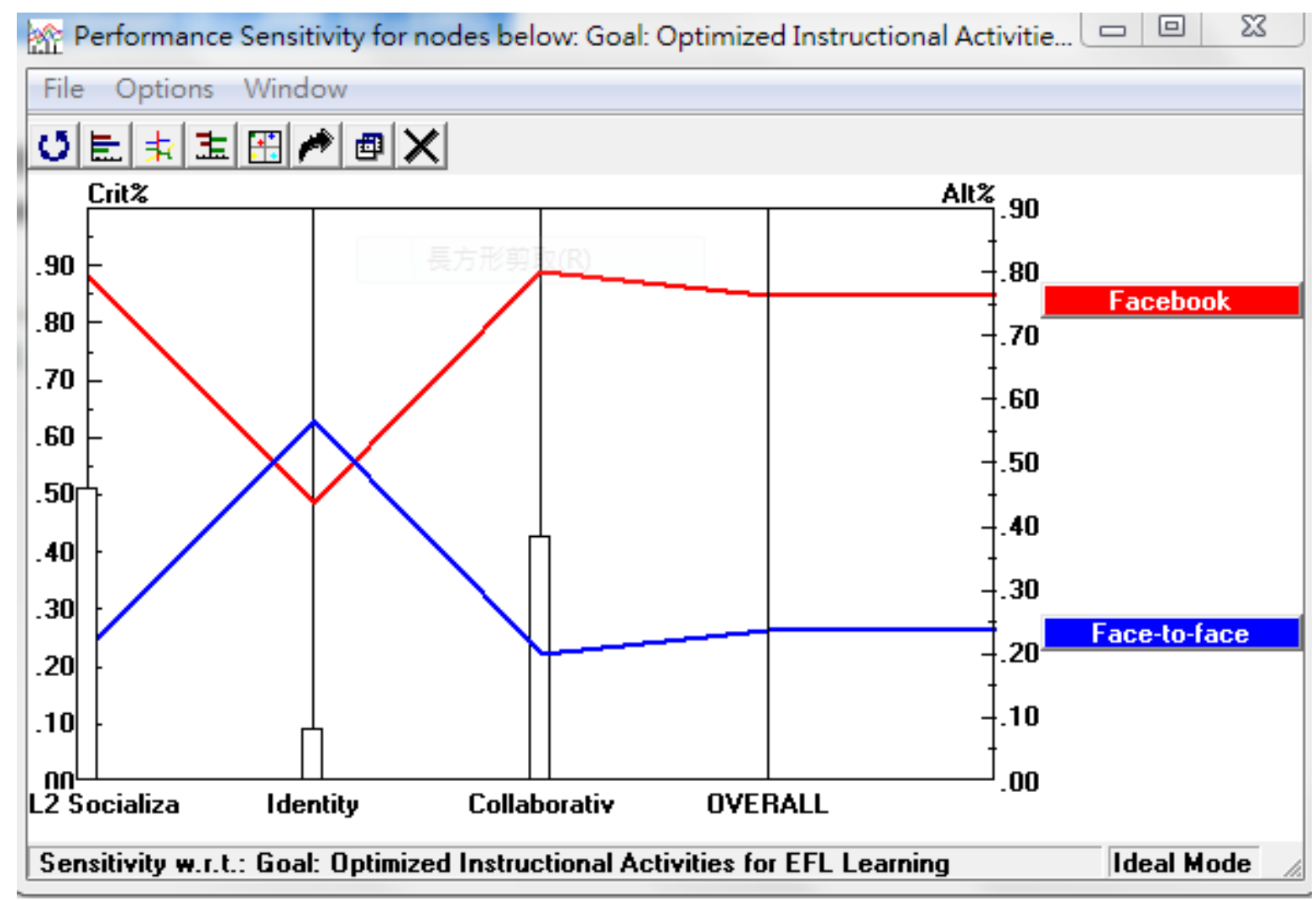

Figure 6. Sensitivity Analysis of Three Criterions and Two Alternatives

The total weights of the two alternatives are .238 for face-to-face and .762 for Facebook, which refers to results based upon the information elicited by the Expert Choice software. Participants in this study thought Facebook was almost (97\%) the perfect channel for instructional activities in EFL learning. According to the information elicited in Table 1, interactivities on Facebook received the highest priority (.315) followed by enjoyableness of 
learning (.240). Therefore, it can be stated that participants were most impressed by their perceived interactivities on Facebook for L2 socialization, as compared to other variables. This finding not only confirms statements by Lantolf (2007) and Norton and Gao (2008), but also attests to what Facebook is able to do regarding interactivities for EFL learning. Because it has been acknowledged that interacting within virtual environments may overcome the communication difficulties found in the face-to-face environment (Minocha, 2009).

Overall, the "Identity" variable was not considered as critical as the other two. This may be attributed to the fact that most members of the CoP (face-to-face or Facebook) were classmates or friends. The issue of identity did not create any barriers for any of the interactivities between them. However, one interesting fact that is worth noting is that participants thought the relationship between members within the $\mathrm{CoP}$ was much more crucial in face-to-face interactions than in a virtual environment, such as Facebook. This piece of information may contradict the claims by Reinhart \& Zander (2011), and Miceli et al. (2010)who argued that virtual environments enable members to maintain close relationships with their peers. Since "students themselves can take the initiative through their creative use and understanding of digital technologies and virtual environments to transform L2 learning, interesting questions are raised about identity roles and relationships in the L2 classroom" (Ushioda, 2011, p. 207). Another way to interpret this result is that Facebook members believed that a relationship could be maintained effortlessly within the virtual environment. From this perspective, this study is in agreement with previous studies. Future studies may investigate this issue through the social capital lens, to elicit a comprehensive picture on how social network sites can influence EFL learners' social capital, both virtually and physically (Perkins \& Long, 2002).

Concerning the facet of collaborative learning, the results of the AHP analysis indicated that the net generation EFL learners claimed that social network sites, such as Facebook, did a better job of raising their motivation levels to communicate with peers in English. One possible reason might be that meaningful online communications allow EFL learners to deliberate their language before making contributions, which further improves the quality of interactions(Freiermuth, 2001; Nor et al., 2012). Moreover, in the virtual CoP established on Facebook, all of the members were silent and thus communications could not be dominated by anyone particular member's loud voice (Freiermuth, 2001). However, the difference in promoting the collaborative learning created by Facebook was not as significant as the other variable: pleasure. Participants had much more fun socializing on Facebook than face-to-face. This result not only echoed prior studies (Minocha, 2009; Kao, Lin \& Sun; Ducate \& Lomicka, 2008) but also augmented the knowledge about exploiting social network sites to diversify EFL learners' interactivities in English.

\section{Conclusion and Limitations}

Social Networking Sites (SNS), such as Facebook, are greatly exploited by students because of the technological support, as well as the affordance, which keep students continuously engaged. Students' strong interests and frequent engagements in SNS have attracted the attention of both practitioners and scholars. Instructors have started to design and conduct 
instructional activities on SNS while researchers have begun to dedicate their efforts to exploring the influence on students' learning. This study focused on investigating the idea of Taiwanese EFL learners' engagements within a Community of Practice (CoP) on Facebook. The results were consistent with a study done by Kabilan (2010), which suggested that through interactions with their Facebook friends in a target language, students were able to: learn new vocabulary, build their self-confidence, increase their motivation and have a positive attitude towards language learning. Participants in this study reported that they enjoyed the experience and were interested in interacting with their peers in English. Also, they also felt comfortable and free to express their opinions and share their thoughts within the CoP, on Facebook. However, results from the observations and focus group interviews indicated that participants in this study pointed out factors that affected their engagement within the $\mathrm{CoP}$ and on Facebook: audience, amount of peer feedback, topic preference, upcoming assignments and examinations, as well as the novelty aspect. These factors suggest that the $\mathrm{CoP}$ is an ideal environment for language learning, a conclusion that was supported by the post AHP analysis. The global weight for Facebook was .762, and 97\% participants perceived that it was the perfect platform for EFL learning. Even so, EFL learners' motivation and engagement can still be influenced by external distractions. Instructors should pay attention to these factors when applying SNS to their teaching. Future studies should focus on how to mitigate the influence of these factors and to strengthen the EFL learner's motivation and engagement in other similar environs on SNS.

Concerning the research's limitations, caution is advised when interpretations are made based on the results of this study. The first limitation, with constraints on the generalizability of this study, is the participants' backgrounds, all of whom were English majors and therefore, might have stronger intrinsic motivations. Since motivation plays a vital role in EFL learning (Hsu, 2011b), future studies may arrive at different results when replicating this research using students of various academic backgrounds. Another limitation is the length of time that the participants interacted on Facebook. Since time is related to the learner's perception of the novelty aspect, fellow scholars would be advised to design longitudinal studies to understand the bigger picture on the pros and cons of using Facebook for EFL learning. Last but not least, findings in this study indicated that EFL learners' motivation can be a critical drive for sustainable engagements in L2 socialization but future research may shed further light on this issue.

\section{References}

Arthur, D., Sherman, C., Appel, D., \& Moore, L. (2006). Why young consumers adopt interactive technologies: A valued-based approach. Young Consumers, 7(3), 33-38.

Badri, M. A., \& Abdulla, M. H. (2004). Awards of excellence in institutions of higher education: an AHP approach. International Journal of Educational Management, 18(4), 224-242. http://dx.doi.org/10.1108/09513540410538813

Barnes, K., Marateo, R. C., \& Ferris, S. P. (2007). Teaching and Learning with the Net Generation. Innovate, 3(4), 771-772. 
Brown, K. G., \& Ford, J. K. (2002). Using computer technology in training: Building an infrastructure for active learning. In K. Kraiger (Ed.), Creating, implementing, and maintaining effective training and development: State-of-the-art lessons for practice (pp. 192-233). San Francisco, CA: Jossey-Bass.

Bumgarner, B. A. (2007). You have been poked: Exploring the uses and gratifications of Facebook among emerging adults. First Monday, 12(11).

Carlson, S. (2005). The Net Generation goes to college. The Chronicle of Higher Education, $52(7)$, A34.

Chen, C. -H., \& Chen, C. -Y. (2012). Instructional approaches on science performance, attitude and inquiry ability in a computer-supported collaborative learning environment. The Turkish Online Journal of Educational Technology, 11(1), 113-122.

Cheng, C. K., Paré, D. E., Collimore, L.-M., \& Joordens, S. (2011). Assessing the effectiveness of a voluntary online discussion forum on improving students' course performance. Computers \& Education, 56(1), 253-261. http://dx.doi.org/10.1016/j.compedu.2010.07.024

Chow, W. S., \& Chan, L. S. (2008). Social network, social trust and shared goals in organizational knowledge sharing. Information \& Management, 45(7), 458-465.

Colpaert, J. (2006). Pedagogy-driven design for online language teaching and learning. CALICO Journal,, 23(3), 477-497.

Denzin, N. K., \& Lincoln, Y. S. (2000). Handbook of Qualitative Research (2nd ed.). Thousand Oaks, CA: Sage Publication.

Ducate, L. C., \& Lomicka, L. L. (2008). Adventures in the blogosphere: from blog readers to blog writers. Computer Assisted Language Learning, 21(1), 9-28. http://dx.doi.org/10.1080/09588220701865474

Duff, P. A. (2007). Second language socialization as sociocultural theory: Insights and issues. Language Teaching, 40(4). http://dx.doi.org/10.1017/s0261444807004508

Ellison, N. B., Steinfield, C., \& Lampe, C. (2007). The benefits of Facebook "friends:" Social capital and college students' use of online social network sites. Journal of Computer-Mediated Communication, $\quad 12(4), \quad$ article $\quad 1$. http://jcmc.indiana.edu/vol12/issue4/ellison.html

Fallon, G., \& Brown, R. B. (2002). Focusing on focus groups: Lessons from a research project involving a Bangladeshi community. Qualitative Research, 2, 195-208.

Freiermuth, M. R. (2001). Native Speakers or Non-Native Speakers: Who Has the Floor? Online and Face-to-Face Interaction in Culturally Mixed Small Groups. Computer Assisted Language Learning, 14(2), 169-199. http://dx.doi.org/10.1076/call.14.2.169.5780

Garrett, P. B., \& Baquedano-López, P. (2002). Language socialization: Reproduction and continuity, transformation and change. Annual Review of Anthropology, 31, 339-361 
Ge, Z.-G. (2011). Exploring e-learners' perceptions of net-based peer-reviewed English writing. ijcscl 6(1), 75-91. http://dx.doi.org/10.1007/s11412-010-9103-7

Ghazvini, S. D., \& Khajehpour, M. (2011). Attitudes and motivation in learning English as second language in high school students. Procedia - Social and Behavioral Sciences, 15, 1209-1213. http://dx.doi.org/10.1016/j.sbspro.2011.03.264

Glenn, J. M. (2000). Teaching the Net Generation. Business Education Forum, 54(3), 6-14.

Graffigna, G., \& Bosio, A. C. (2006). The influences of settings on findings produced in qualitative health research: A comparison between face-to-face and on-line discussion groups about HIV/AIDS. International Journal of Qualitative Methods, 5(3), 55-76.

Haneda, M. (1997).Second language learning in a 'Community of Practice': A case study of adult Japanese learners. Canadian Modern Language Review, 54(1), 11-24. http://dx.doi.org/10.3138/cmlr.54.1.11

Hay, L. E. (2000). Educating the Net Generation. The Social Administrator, 57(54), 6-10.

Hennick, M. M. (2008). Emergent issues in international focus group discussion. In S. N. Hesse-Biber \& P. Leavy (Eds.), Handbook of emergent methods (pp. 207-220). New York: Guildford Press New York.

Holmes, J., \& Meyerhoff, M. (1999). The Community of Practice: Theories and methodologies in language and gender research. Language in Society, 28, 173-183.

Hooff, B. v. d., \& Huysman, M. (2009). Managing knowledge sharing: Emergent and engineering approaches. Information \& Management, 46(1), 1-8.

Hsu, L. W. (2011). To Be Computerized or Not to Be?A Study on EFL Learners' Perceptions towards Various Modes of Delivery in English Tests through Analytic Hierarchy Process.International Journal of Current Research, 3(5), 170-176

Hsu, C. L., \& Lin, J. C. (2008). Acceptance of blog usage: the roles of technology acceptance, social influence and knowledge sharing motivation. Information \& Management, 45(1), 65-74. http://dx.doi.org/10.1016/j.im.2007.11.001

Huang, J. J. S., Yang, S. J. H., Huang, Y. -M, \& Hsiao, I. Y. T. (2010). Social learning networks: Build mobile learning networks based on collaborative service. Educational Technology \& Society, 13(3), 78-92.

Huang, Y.-M., Chiu, P.-S., Liu, T.-C., \& Chen, T.-S. (2011). The design and implementation of a meaningful learning-based evaluation method for ubiquitous learning. Computers \& Education, 57, 2291-2302. http://dx.doi.org/10.1016/j.compedu.2011.05.023

Ishizaka, A., \& Labib, A. (2009). Analytic Hierarchy Process and Expert Choice: Benefits and limitations. OR Insight, 22(4), 201-220.http://dx.doi.org/10.1057.ori.2009.10

Jou, Y. S. (2013). Sociolinguistic approaches to identity negotiation and language learning: A circumstantiality perspective on communities of practice. International Journal of Research 
Studies in Language Learning, 2(1), 49-60.

Jowett, M., \& O'Toole, G. (2006). Focusing researchers' minds: Contrasting experiences of using focus groups in feminist qualitative research. Qualitative Research, 6, 453-472.

Junco, R. (2011). The relationship between frequency of Facebook use, participation in Facebook activities, and student engagement. Computers \& Education, 58, 162-171. http://dx.doi.org/10.1016/j.compedu.2011.08.004

Kabilan, M. K., Ahmad, N., \& Abidin, M. J. Z. (2010). Facebook: An online environment for learning of English in institutions of higher education? The Internet and Higher Education, 13(4), 179-187. http://dx.doi.org/10.1016/j.iheduc.2010.07.003

Kaulback, B., \&Bergtholdt, D. (2008).Holding the virtual space: The roles and responsibilities of community stewardship. In C. Kimble, P. Hildreth, \& I. Bourdon (Eds.), Communities of practice: Creating learning environments for educators (Vol. 2, pp. 25-44). Charlotte, NC: Information Age.

Kainulainen, T., Leskinen, P., Korhonen, P., Haara, A., \& Hujala, T. (2009). A statistical approach to assessing interval scale preferences in discrete choice problems. Journal of the Operational Research Society, 60(2), 252-258. http://dx.doi.org/10.1057/palgrave.jors.2602554

Kao, G. Y.-M., Lin, S. S. J., \& Sun, C.-T. (2008). Beyond sharing: Engaging students in cooperative and competitive active learning. Educational Technology \& Society, 11(3), 82-96.

Kasper, G. (2001). Four perspectives on L2 pragmatic development. Applied Linguistics, $22(4), 502-530$.

Kim, H. K. (2011). Promoting communities of practice among non-native speakers of English in online discussions. Computer Assisted Language Learning, 24(4), 353-370. http://dx.doi.org/10.1080/09588221.2011.572899

Ko, C. -J. (2012). Can synchronous computer-mediated communication (CMC) help beginning-level foreign language learners speak? Computer Assisted Language Learning, 25(3), 217-236. http://dx.doi.org/10.1080/09588221.2011.649483

Krueger, R. A., \& Casey, M. A. (2009). Focus Groups: A Practical Guide for Applied Research. Thousand Oaks, CA: Sage Publications, Inc.

Lai, C., \& Gu, M. (2011). Self-regulated out-of-class language learning with technology. Computer Assisted Language Learning, 24(4), 317-335. http://dx.doi.org/10.1080/09588221.2011.568417

Lampe, C., Wohn, D. Y., Vitak, J., Ellison, N., \& Wash, R. (2011). Student use of Facebook for organizing collaborative classroom activities. International Journal of $\begin{array}{llll}\text { Computer-Supported Collaborative } \quad \text { Learning, } & 6,\end{array}$ http://dx.doi.org/10.1007/s11412-011-9115-y

Lantolf, J. P., \& Thorne, S. L. (2007). Socialcultural theroy and second language learning. In 
B. VanPatten \& J. Williams (Eds.), Theories in Second Language Acquisition: An Introduction. New York: Routledge

Levy, M. (2009). Technologies in use for second language learning. The Modern Language Journal, 3, 769-782.

Lincoln, Y. S., \& Cuba, E. G. (1985). Naturalistic Inquiry. Newbury Park, CA: Sage Publication.

Lin, K. -Y., \& Lu, H.- P. (2011). Why people use social networking sites: An empirical study integrating network externalities and motivation theory. Computers in Human Behavior, 27(3), 1152-1161. http://dx.doi.org/10.1016/j.chb.2010.12.009

Mazer, J. P., Murphy, R. E., \& Simonds, C. J. (2007). I'll see you on "Facebook": The effects of computer-mediated teacher self-disclosure on student motivation, Affective Learning, and Classroom Climate. Communication Education, 56(1), 1-17. http://dx.doi.org/10.1080/03634520601009710

Mazman, S. G., \& Usluel, Y. K. (2010). Modeling educational usage of Facebook. Computers \& Education, 55(2), 444-453. http://dx.doi.org/10.1016/j.compedu.2010.02.008

McLoughlin, C., \& Lee, M. J. W. (2007). Social software and participatory learning: Pedagogical choices with technology affordances in the web 2.0 era. Paper presented at the ICT: Providing choices for learners and learning. Proceedings ascilite Singapore 2007.

Merriam, S. B., \& Simpson, E. L. (1995). A guide to research for educators and trainers of adults (2nd ed.). Malabar, FL: Krieger.

Miceli, T., Murray, S. V., \& Kennedy, C. (2010). Using an L2 blog to enhance learners' participation and sense of community. Computer Assisted Language Learning, 23(4), 321-341. http://dx.doi.org/10.1080/09588221.2010.495321

Minocha, S. (2009). A case study-based investigation of students' experiences with social software tools. New Review of Hypermedia and Multimedia, 15(3), 245-265. http://dx.doi.org/10.1080/13614560903494320

Mitchell, K. (2012). A Social Tool: Why and How ESOL Students Use Facebook. CALICO Journal, 29, 471-493.

Montero, B., Watts, F., \& Garcia-Carbonell, A. (2007). Discussion forum interactions: Text and context. System, 35, 566-582.

Morita, N. (2004). Negotiating participation and identity in second language academic communities.TESOL Quarterly, 38, 573 - 601.

Nation, I. S. P. (2001).Learning vocabulary in another language. Cambridge, UK: Cambridge University Press.

Nikander, Pirjo. (2008). Working with Transcripts and Translated Data. Qualitative Research 
in Psychology, 5(3), 225-231. http://dx.doi.org/10.1080/14780880802314346

Nor, F. M., Hamat, A., \& Embi, M. A. (2012). Patterns of discourse in online interaction: seeking evidence of the collaborative learning process. Computer Assisted Language Learning, 25(3), 237-256. http://dx.doi.org/10.1080/09588221.2012.655748

Norton, B., \& Gao, Y. (2008). Identity, investment, and Chinese learners of English. Journal of Asian Pacific Communication, 18(1), 109-120.

Norton, B., \& Toohey, K. (2002). Identity and language learning. In R. B. Kaplan (Ed.), The Oxford Handbook of Applied Linguistics (pp. 115-123). Oxford: Oxford University Press.

Oblinger, D. G., \& Oblinger, J. L. (2005). Educating the Net Generation. Boulder, CO: Educause.

Olivares, O. J. (2007). Collaborative vs. Cooperative Learning: The Instructor's Role in Computer-Supported Collaborative Learning. In K. L. Orvis \& A. L. R. Lassiter (Eds.), Computer-supported collaborative learning: Best practices and principles for instructors (pp. 20-39). Hershey, PA: Information Science Publishing.

Orvis, K. L., \& Lassiter, A. L. R. (2006). Computer-supported collaborative learning: The role of the instructor. In S. P. Ferris \& S. H. Goodard (Eds.), Teaching and learning with virtual teams (pp. 158-179). Hershey, PA: Information Science Publishing.

Pasfield-Neofitou, S. (2011). Online domains of language use: second language learners' experiences of virtual community and foreignness. Language Learning \& Technology, 15(2), 92-108.

Pempek, T. A., Yermolayeva, Y. A., \& Calvert, S. L. (2009). College students' social networking experiences on Facebook. Journal of Applied Developmental Psychology, 30(3), 227-238. http://dx.doi.org/10.1016/j.appdev.2008.12.010

Perkins, D. D., \& Long, D. A. (2002). Neighborhood sense of community and social capital: A multi-level analysis. In C. S. A. Fisher \& B. Bishop (Eds.), Psychological sense of community: Research, applications, and implications (pp. 291-318). New York: Plenum.

Rachel, P. (2008). Communities of practice: Using the open web as a collaborative learning platform. iLearning Forum 2008 Proceedings, Paris.

Reinhardt, J., \& Zander, V. (2011). Social networking in an intensive English program classroom: A language socialization perspective. CALICO Journal, 28(2), 326-344.

Rodriguez, K. L., Schwartz, J. L., Lahman, M. K. E., \& Geist, M. R. (2011). Culturally responsive focus groups: Reframing the research experience to focus on participants. International Journal of Qualitative Methods, 10(4), 400-417.

Ricento, T. (2005). Considerations of identity in L2 learning. In E. Hinkel (Ed.), Handbook of research on second language teaching and learning (pp. 895-911). Mahwah, NJ: Lawrence Erlbaum Associates. 


\section{Macrothink}

International Journal of English Language Education

ISSN 2325-0887

2013, Vol. 1, No. 3

Saaty, T. L. (1990). How to make a decision: The analytic hierarchy process. European Journal of Operational Research, 48(1), 9-26.

Saaty, T. L. (1994). How to make a decision: The analytic hierarchy process. Interfaces, 24(6), 9-26.

Saaty, T. L. (2008). Decision making with the analytic hierarchy process International Journal of Services Sciences, 1(1), 83-98. http://dx.doi.org/10.1504/IJSSci.2008.01759

Sandars, J., \& Morrison, C. (2007). What is the Net Generation? The challenge for future medical education. Medical Teacher, 29(2/3), 85-88. http://dx.doi.org/10.1080/01421590601176380

Shee, D. Y., \& Wang, Y.-S. (2008). Multi-criteria evaluation of the web-based e-learning system: A methodology based on learner satisfaction and its applications. Computers \& Education, 50(3), 894-905. http://dx.doi.org/10.1016/j.compedu.2006.09.005

Shih, R. -C. (2011). Can Web 2.0 technology assist college students in learning English writing? Integrating Facebook and peer assessment with blended learning. Australasian Journal of Educational Technology, 27(5), 829-845.

Shin, S. K., Ishman, M., \& Sanders, G. L. (2007). An empirical investigation of socio-cultural factors of information sharing in China. Information \& Management, 44(2), 165-174.

Stutzman, F. (2006). An evaluation of identity-sharing behavior in social network communities. iDMAa Journal, 3(1).

Swain, M., \& Deters, P. (2007). "New" mainstream SLA theory: Expanded and enriched. The Modern Language Journal, 91, 820-836.

Tama, M. C. Y., \& Tummalab, V. M. R. (2001). An application of the AHP in vendor selection of a telecommunications system. Omega, 29, 171-182.

Ushioda, E. (2011). Language learning motivation, self and identity: current theoretical perspectives. Computer Assisted Language Learning, 24(3), 199-210. http://dx.doi.org/10.1080/09588221.2010.538701

Warschauer, M. (2002). Networking into academic discourse. Journal of English for Academic Purposes, 1(1), 45-58.

Wenger, E. (1998). Communities of Practice: Learning, Meaning, and Identity. Cambridge: Cambridge University Press.

Wenger, E., McDermott, R., \& Snyder, W. M. (2002).Cultivating communities of practice.Harvard Business School Press.

Xu, G. (2010). Understanding the Role of Interaction From Linguistic, Affective, and Social Perspectives. TESL Canada Journal, 27(2), 68-88.

Yang, Y. -F. (2011). Engaging students in an online situated language learning environment. Computer Assisted Language Learning, 24(2), 181-198. 


\section{Macrothink

http://dx.doi.org/10.1080/09588221.2010.538700

Yu, A. Y., Tian, S. W., Vogel, D., \&Kwok, R. C. -W. (2010). Can learning be virtually boosted? An investigation of online social networking impacts. Computers \& Education, 55(4), 1494-1503. http://dx.doi.org/10.1016/j.compedu.2010.06.015

Yunus, M. M., Salebi, H., \& Chen, C.. (2012). Integrating Social Networking Tools into ESL Writing Classroom: Strengths and Weaknesses. English Language Teaching, 5(8), 42-48. http://dx.doi.org/10.5539/elt.v5n8p42

Zurita, G., \& Nussbaum, M. (2004). Computer supported collaborative learning using wirelessly interconnected handheld computers. Computers \& Education, 42(3), 289-314. http://dx.doi.org/10.1016/j.compedu.2003.08.005

\section{Copyright Disclaimer}

Copyright reserved by the author(s).

This article is an open-access article distributed under the terms and conditions of the Creative Commons Attribution license (http://creativecommons.org/licenses/by/3.0/). 